\title{
DISCUSSION
}

\section{A critique of the principle of error correction as a theory of social change}

\author{
M A R K C. LE W IS \\ University of Pennsylvania, USA
}

\section{A B S T R A C T}

This article assesses the historical failures and limits of the dominant 'error correction' approach within sociolinguistics. The error correction approach supposes that social change can be achieved when knowledge is shared by researchers with the public or figures of institutional authority. This article reviews reflections on sociolinguists' work toward social change, especially those of Labov, through scholarship in language ideologies and critical race theory. From a language ideological and critical race perspective, error correction is limited in its engagement with marginalizing representations of language because it does not jointly address material conditions and social positions supported by these representations. Exemplifying these limitations, sociolinguistic error-correction efforts that address the evaluation of language practices racialized as Black may have unfortunately distracted from social change agendas that confront material and institutionalized racism directly. To address these limitations, this article highlights existing critical reflexive scholarship that explicitly interrogates disciplinary assumptions. (Critical race theory, error correction, language ideologies, social change, critical reflexivity)*

\section{N T R O D U C T I O N}

Sociolinguists often conduct their research with social change goals in mind, aiming to improve social conditions for participants in their research or other members of a society. However, little explicit attention has been given to assumptions about how such change might occur. The widespread error correction approach supposes that social change can be achieved when researchers share knowledge they produce with the public or specific institutional authorities. Accordingly, many works about applying the findings of sociolinguistics are 
structured to correct harmful misconceptions (e.g. Wiley 1997; Bauer \& Trudgill 1998; McWhorter 1998; Zuidema 2005). While the failures of the error correction approach are sometimes noted, it remains standard in the field and has not been reconsidered in the years since its description by William Labov, who articulated and modeled the principle of error correction (PEC) as a guide to public engagement. The PEC offers a theoretical starting place for diverse social-change efforts without specifying precise organizational strategies for outreach efforts. In this article, I apply critical race theory and scholarship in language ideologies to critique the PEC as theory of social change. After describing these areas of scholarship in more detail, I review work in which sociolinguists have reflected on the continued difficulties of error correction without fundamentally moving beyond its premises. I review Labov's influential writings on error correction to examine those premises further. Finally, I highlight scholarship on language, hierarchy, and social change that takes critical reflexive positions on research in ways that offer alternatives to the PEC.

While error correction efforts have been pursued about many sociolinguistic issues (e.g. Bauer \& Trudgill 1998), my discussion of the PEC's development and persistence in the field focuses on scholarship on the social evaluation of language practices known as African American Vernacular English, Black English, Black Language, African American Language, or Ebonics, among other terms (for discussions of terminology see Morgan 1994; Baugh 2000; Mufwene 2001). ${ }^{1}$ Language practices racialized as Black have been crucial to the development of sociolinguistics in the United States as well as the focus of the field's most prominent public error correction efforts (Rickford 1997). While scholarship on these practices thus serves as the best illustration of error correction, my critique of the PEC is not limited to this scholarship alone, and broader implications of this discussion are raised in the conclusion of the article. Labov's (1982) article 'Objectivity and commitment in linguistic science: The case of the Black English trial in Ann Arbor' (hereafter, OCLS), often cited in overviews of linguistics and sociolinguistics (e.g. Wolfram 1997; Milroy \& Gordon 2003; L. Rice 2007; Johnson 2013), is among the most famous arguments about social-change efforts by linguists and, as its title suggests, describes scholarly contributions to legal determinations about Black English and the educational rights of Black children. This trial came to center on whether the plaintiffs could 'show that the school had neglected to overcome language barriers' in the education of the Black children in the Ann Arbor, Michigan school district (OCLS:170). Labov describes his work as a member of a team of experts, convened by Geneva Smitherman, that consulted with plaintiffs' attorneys and testified in court, and he uses the case to propose and discuss the PEC as a guide to sociolinguistic research that works toward social change. Labov (OCLS:172) hoped that such a principle would help resolve the apparent tension, referenced in the title of the article, between 'objectivity needed for linguistic research and commitment to a social position in an adversary situation'. The PEC itself is provided shortly after: 
A scientist who becomes aware of a widespread idea or social practice with important consequences that is invalidated by his own data is obligated to bring this error to the attention of the widest possible audience. (OCLS:172)

The PEC assumes that social change can be accomplished by changing the beliefs of a large number of people through the dissemination of knowledge produced by researchers, an assumption that has persisted within sociolinguistics.

Many ideas that would be considered errors from the perspective of sociolinguists still enjoy wide circulation in the US, despite decades of error correction efforts. Labov's (1972c) essay 'The logic of nonstandard English' (hereafter, LNE), which Labov cites as an example of the work the PEC promotes, offered a refutation of the verbal deprivation thesis applied to Black children in urban schools, but claims like the verbal deprivation thesis are still widespread and continue to have important consequences in US schooling. Among other guises, this thesis can now be seen expressed again as the so-called word gap, and it continues to figure in policymaking about public schooling and even child rearing (Avineri et al. 2015; Aggarwal 2016). In the history of US education, the verbal deprivation thesis is not an anomaly. The educational psychologists who developed it were merely the next in line of generations of linguistic and educational scholars who have claimed to demonstrate the inferiority of language practices racialized as Black (for further historical review see Smitherman-Donaldson 1988; Smitherman 2015). Ann Arbor was neither the beginning nor the end of marginalizing ideologies for which sociolinguistic scholarship provides unheard answers, yet Labov's optimistic view of the involvement of sociolinguists in the trial's outcome has framed the dominant theory of social change in the field. The practical outcome of the 1977 Ann Arbor case, which the plaintiffs and sociolinguistics both ostensibly won, left hope for significant change unfulfilled. As Smitherman (2004) summarized in a retrospective of the case:

\footnotetext{
First, the district sought no outside funding and the plan was, by deliberate design, seriously underfunded. Second, the plan was scheduled to last only one year, during which there were to be twenty hours of in-service language instruction for King School staff, which they would be paid to attend, a library with materials on Black and Standard English, a language arts consultant-specialist with expertise in Black English, and four sessions for reading teachers. Amazingly, the plan specified no special language and literacy instruction for the plaintiff children. Further, Ann Arbor's proposed oversight team included no parent representatives, none of the community and professional folks who had become advocates for the King students ('Friends of King', as we deemed ourselves), none of the nationally prominent team of linguists and educators whom I had organized and who had testified as expert witnesses during the trial, no representatives of the Ann Arbor Student Advocacy Center that had been counseling and assisting the Green Road mothers for years, and no teachers from any other school in the Ann Arbor district. (Smitherman 2004:189)
}

Examining the error correction approach's premises about social change reveals its limits, which explain why even apparent victory in error correction fails to achieve its goals. The limits of an error correction approach originate in a theory of social change that contains assumptions about the nature of racism and the importance of evidence in the construction of representations of language. 
To explore and critique these assumptions, I draw on scholarship in language ideologies as well as critical race theory (CRT). While the PEC assumes that consequential claims about language exist mainly as ideas possessed by individuals, scholarship on language ideologies seeks a broader understanding of representations of language as always linked to the interests of differently positioned social actors and often embedded within institutionalized practices (Woolard \& Schieffelin 1994; Woolard 1998; Irvine \& Gal 2000; Kroskrity 2000; Rosa \& Burdick 2016). Critical race theory explains the persistence of racism by highlighting the material consequences for those it targets and for those it benefits. Most relevant for understanding the PEC, CRT argues that racism's persistence partly relies on dominant discourses on racism that obscure its origins and consequences (Delgado 1989; Delgado \& Stefancic 2001; Hill 2008; Crump 2014; Richardson 2015). In this article, I apply a CRT framework to sociolinguistic scholarship to reveal notions about racism that have been taken for granted through PEC-inspired work. After describing reflections on public engagement within sociolinguistic scholarship that have not reconsidered the PEC's theory of social change, I analyze OCLS and LNE to illustrate their assumptions about racism, social change, and representations of language. In the closing of this article, I highlight scholarship with critical reflexive stances that bring the PEC's assumptions into question and model alternative approaches to scholarship in the interest of social change.

\section{J O INING LANGUAGE IDEOLOGIES A D \\ C R I T I C A R A C E THE R Y}

Language ideology scholarship examines the inseparability of language use, social groupings, and representations of language (Silverstein 1985; Woolard \& Schieffelin 1994; Woolard 1998; Irvine \& Gal 2000; Kroskrity 2000; Rosa \& Burdick 2016). Woolard (1998:3) defines language ideologies as 'representations, whether explicit or implicit, that construe the intersection of language and human beings in a social world'. In the sense that it offers alternatives to placing beliefs about language at the center of analysis, language ideology scholarship suggests alternatives to the PEC. While some scholars discuss language ideology in terms of belief (e.g. Lippi-Green 1997; Wolfram 1998; J. Milroy \& L. Milroy 1999; Wassink \& Curzan 2004; Smitherman 2015), a departure from focusing on beliefs is central to my critique of the PEC. In this understanding, ideologies are not located mentally as beliefs (no matter how widely reported) or structurally as hegemonic patterns that determine social action. Instead, they are 'signifying practices that constitute social subjects' and are involved in relations of, for example, 'affiliation, intimacy, and identity, all of which are complexly imbricated with but not directly and simply equatable to power' (Woolard 1998:8).

As Woolard describes, essential to this approach is seeing ideologies as representations that are material, perceivable, and often embedded in institutionalized 
practices such as, in the case of marginalized language practices in schools, curricula or teacher training materials. In contrast, the PEC invokes ideas, practices, and consequences, but the campaigns it is used to justify overwhelmingly frame solutions as consisting of changing ideas or beliefs by the dissemination of evidentiary claims about language. For example, having identified practices that ought to change, PEC-inspired efforts might seek to identify the beliefs that inform those practices and target those beliefs for change, assuming that this will naturally change the associated practices. In contrast, scholarship informed by language ideology frameworks could focus on the same practices, with similar ultimate socialchange goals and still devoted squarely on consequences, but it would not attempt to document beliefs as causing a social problem. Instead of extracting beliefs from the totality of practices around language, this approach asks How language is represented, WHAT material circumstances these representations support, and WHICH social positions are occupied by actors representing language in these ways.

To reconsider the PEC's theory of social change, language ideology scholarship can be joined with the specific insights of critical race theory. Toward the goal of complicating and extending theories of social change, both language ideology scholarship and CRT are unified in seeing representations of language as always inseparable from sociohistorical processes, which involve more than beliefs expressed by individuals. In scholarship focused on the United States, CRT insists that racism is endemic to society and remains essential to the persistence of educational inequity (Ladson-Billings \& Tate 1995). Much like the scholarship supporting the PEC as a dominant theory of social change within sociolinguistics, CRT was developed in response to the specific sociohistorical context of the United States, though it has been taken up in other contexts as well (e.g. Gillborn 2005). Across contexts, CRT 'dares to look beyond the popular belief that getting rid of racism means simply getting rid of ignorance, or encouraging everyone to "get along" (A. Harris 2001:xx). In contrast to liberal narratives of progress toward legal equality, CRT highlights how legal changes such as those brought by the Brown v. Board of Education school desegregation ruling of the US Supreme Court are often structured to minimize threats to the material interests of White people and normalize or erase histories of institutionally enforced white supremacy (Bell 1980; Ladson-Billings \& Tate 1995; Delgado \& Stefancic 2001; Aggarwal 2016). Addressing the steps necessary to end such a deeply embedded problem, CRT addresses a distinction between two theories of racism, idealist and materialist. The idealist perspective describes racism as 'matters of thinking, mental categorization, attitude, and discourse' and thus proposes to eliminate it by 'changing the system of images, words, attitudes, unconscious feelings, scripts, and social teachings' that it involves (Delgado \& Stefancic 2001:17). By contrast, the materialist perspective describes racism as 'more than having an unfavorable impression of members of other groups' and instead as 'a means by which society allocates privilege and status', made of 'racial hierarchies' that 'determine who gets tangible benefits' (Delgado \& Stefancic 2001:17). Therefore, for 
materialists, 'physical circumstances' are the most appropriate target for the abatement of racism (Delgado \& Stefancic 2001:20).

In summarizing CRT, Delgado \& Stefancic (2001:20) are open to the possibility that idealist and materialist approaches to ending racism might co-exist in a middle approach that attacks racism originating from 'both forces, material and cultural, operating together and synergizing each other'. On this point, joining critical race theory and language ideology perspectives reveals a tension: in the linguistic anthropological tradition from which language ideology scholarship originates, the distinction between the 'cultural' and the 'material' is a false one. Describing the possible value of anthropological understandings of 'culture' for CRT would be an entirely different (but worthy) project, and for the purposes of my argument, this tension is largely a commensurable terminological issue. After all, the cultural forms Delgado \& Stefancic say that the idealists want to change (e.g. teachings, scripts, systems of images and words) are material in that they are perceivable representations of language and people or widely reportable regularities of behavior.

Despite a body of work that jointly considers race and the evaluation of racialized language (e.g. Hill 1998, 2008; Bucholtz 1999; Bonfiglio 2002; Kubota \& Lin 2006; Alim \& Smitherman 2012; Crump 2014; Flores \& Rosa 2015; Richardson 2015; Alim 2016; Flores 2016; Rosa 2016), insights from critical race perspectives on language have not yet been applied to the relative undertheorization of racism in proposals motivated by the PEC. Unlike Labov's early writings on error correction, CRT specifically engages with the endemic nature of racism and its historical development. Theorization of social change can benefit from CRT, especially work applied to the study of education in particular, which sometimes bears an impossible weight of expectations for social change. A materialist critical race theory suggests that error correction efforts by sociolinguists focusing on individual beliefs are not sufficient to dismantle white supremacy in the United States, even the aspects of white supremacy expressed through social evaluation of racialized language. To the extent that error correction excludes a materialist and language ideological analysis of racism from social change efforts, it will be counterproductive to ending racism.

THE PERSISTENCE OF ERROR CORRECTION IN

SOCIOLINGUISTIC ACTIVISM AND PUBLIC

E N G A G E M E N T

Recent reviews of the impact of sociolinguistics or Labov's influential career cite the impact of the PEC approvingly without exploring its problems (Rickford 2016; Labov 2016; Lawson \& Sayers 2016; Wolfram 2016). Acknowledgment and discussion of the failures of error correction efforts are more commonly found in more specific reviews of the field's activism in the United States addressing social and institutional evaluation of language practices racialized as Black. At the same time, these works accept the basic premises of the error correction approach. For example, the 'Ebonics controversy' of the late 1990s, a national 
debate spurred by the school district of Oakland, California, which had predominantly African American enrollment, announcing a new educational policy incorporating Ebonics into instruction, served as an opportunity for Rickford to discuss linguists' engagement with the public:

When the Ebonics controversy broke, many linguists expressed frustration at the extent to which the
public still appeared to have misconceptions about this and other vernaculars which we thought we
had long ago dissipated.... However, in harboring this frustration, we seem to have forgotten what
advertisers of Colgate toothpaste and other products never forget; that the message has to be repeated
over and over, anew for each generation and each different audience type, and preferably in simple,
direct and arresting language which the public can understand and appreciate. (Rickford 1999:271)

With his reference to public misconception, Rickford invokes the premises of error correction and addresses primarily tactical concerns: how the message is distributed, how often, and to whom. Rickford also briefly includes another analysis of the problem, after describing 'vicious Ebonics jokes and parodies':

\footnotetext{
In cases like these, language was no longer at issue; 'Ebonics' had become a proxy for African Americans, and the most racist stereotypes were being promulgated. This cruel humor might remind us, however, that behind people's expressed attitudes to vernacular varieties, there are often deepseated social and political fears and prejudices about their speakers. If we don't take the 'socio' part of sociolinguistics seriously, we won't be prepared to understand or respond to such attitudes effectively. (Rickford 1999:272)
}

The first description frames language ideologies as informational, sensitive to correction, and especially sensitive to repeated correction. In contrast, Rickford's second description, while it still views ideologies primarily as individually held attitudes, centers social and political context and ways that representations of language serve as representations of people. Like other accounts of error correction's failures, Rickford's two descriptions do not explore any possible incompatibility between strategies that seek to shift individual beliefs and understandings of racism that center economic and political interests.

Like Rickford, Smitherman (2004:191) connects backlash against Ebonics policies at the Oakland School District to 'the persistence of language myths and misconceptions in the nation's schools' as well as 'the continuing legacy of internalized and externalized racism'. She proposes several strategies to combat these problems. Echoing error correction framings of social change, Smitherman (2004:194) calls for 'a major campaign to go public with our knowledge', particularly though not exclusively in schools, where 'myths and misconceptions about language are reinscribed and reaffirmed'. Beyond a public campaign though, Smitherman (1998, 2004) also proposes comprehensive multilingual education policies along with several other educational reforms. She uses the persistence of misconceptions as evidence for the continued need for error correction. However, the sweeping educational and political change for which she advocates appears to align much more with her political and economic description of the evaluation of African American Language as 'a way of reinscribing the subordination and powerlessness of Black working-class people in this country' than it does with error correction approaches (Smitherman 1998:105). 
In disagreement with Smitherman and Rickford among others, McWhorter (1998) criticizes pedagogical proposals that seek to respond to differences between Black English and Standard English, arguing that such differences are not significant enough to directly cause failure in learning to read. Despite this disagreement, McWhorter still proposes ways to improve error correction and emphasizes the need to correct widely held and mistaken beliefs, illustrating the wide acceptance of the PEC's theory of change. McWhorter highlights political and economic inequalities and proposes error correction efforts such as a training program for teachers to address the 'stigma connected to Black English' (1998:235) as one component of initiatives to improve the educational achievement of Black students. He acknowledges the historical lack of widespread success of these attitude-changing efforts but blames the complexity of the concepts involved, not the pervasiveness of racism he highlights elsewhere (McWhorter 1998:237).

Rickford, Smitherman, and McWhorter acknowledge that error correction efforts sometimes fail to change pervasive evaluations of language practices racialized as Black, and they highlight the role of institutionalized racism in these evaluations, but the premises of error correction itself are not evaluated in their work. Instead, the dominant theory of social change remains, supposing that evidence produced by scholars can indeed motivate members of the public to change their personal beliefs about language, addressing social problems like racism. This theory has only rarely been reconsidered, and even then the premises of the PEC are largely unchallenged. For example, Wolfram's consideration of the PEC from the perspective of both activism and research ethics included proposing the principle of linguistic gratuity, which is regularly cited along with Labov's principles in reviews of sociolinguistic ethics (e.g. L. Milroy \& Gordon 2003:84-85). The gratuity principle encourages the use of linguistic data to 'actively pursue positive ways in which [linguists] can return linguistic favors to the community' (Wolfram 1993:3). Wolfram describes it as a proactive principle in contrast to the reactive PEC, but he does not otherwise critique fundamental premises of the PEC, even when considering some of its unforeseen consequences (Wolfram 2007). Alim (2010) criticizes sociolinguistic research on language and schooling that implicitly accepts the imperative for all students to learn so-called standard dialects. Alim proposes preparing teachers in training with 'a particular set of knowledges and pedagogies' with the goal of 'help[ing] students and teachers abandon old, restrictive and repressive ways of thinking about language and to resocialize them into new, expansive and emancipatory ways of thinking about language and power' (Alim 2010:227-28). These 'ways of thinking about language and power' seem similar to the 'widespread ideas' addressed in the PEC, and accordingly the response of abandonment and resocialization seems similar to the error correction approach. Thus, while Alim pushes the field to do far more than the PEC suggests, there is still a need to consider how teacher-training efforts may be limited by the PEC's theory of social change. 
The legacy of the PEC must be confronted directly as sociolinguists continue to refine strategies for social change, particularly as the variety of contexts in which race and language are linked outpaces past scholarship (Alim 2016). While building on arguments that racism must be included in articulating a response to racialized language ideologies, I see the PEC's focus on errors and misconceptions as counterproductive to social change when it directs attention away from social and political dimensions of racism. The failure of error correction efforts must be understood by examining the PEC's premises about racism, social change, and representations of language.

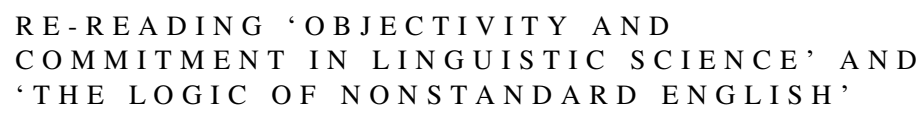

In this section, I apply the contributions of critical race theory and language ideology scholarship to OCLS and LNE as foundational statements of the error correction approach and its theory of social change. The previous section demonstrated that this theory of change has been broadly accepted and largely unchallenged within sociolinguistics, and this section more closely examines the PEC as it is embedded in Labov's influential work. Though these writings address the consequences of social evaluation of language, their guidance for linguists who want to work toward social change center only on individual-centric understandings of language ideology. While OCLS and LNE are intended to work against racism, their underlying assumptions about social change obscure institutional and material aspects of this problem. While OCLS and LNE did not originate idealist theories of racism or individualist theories of language ideology, critical examination of their reliance on these theories reveals problems that sociolinguists can work harder to address.

'Objectivity and commitment in linguistic science' was published in 1982 as an invited paper in Language in Society, as part of a series commemorating the journal's tenth year of publication. OCLS discusses linguists' involvement in the 'Black English trial' of Ann Arbor in order to theorize approaches to social change, and it proposes the principle of error correction. Labov writes that the 'general conception of the paper was first developed at presentations ... during the year of the trial', or 1977 (OCLS:196). 'The logic of nonstandard English' was published well before OCLS, first in 1969 in Georgetown Monographs in Languages and Linguistics 22, then as a chapter in Language in the inner city (Labov 1972b), which summarized much of Labov's research on the Black English Vernacular up to that point. In the introduction to Language in the inner city (xvi), Labov states that this essay was 'widely reprinted', a dissemination that included a 'condensed version' in the June 1972 issue of The Atlantic Monthly, where it was titled 'Academic ignorance and Black intelligence' (Labov 1972a). In this article, I use quotations from the version in The Atlantic Monthly because it was the most publically disseminated, but I also explain important differences between that version and the one 
published in Language in the inner city. LNE is primarily concerned with refuting the 'verbal deprivation thesis', advanced by educational psychologists Carl Bereiter and Siegfried Engelmann, which attributes 'the educational problems of children in ghetto schools' to the fact that the children 'receive little verbal stimulation, to hear little well-formed language, and as a result are impoverished in their means of verbal expression' (LNE; Labov 1972a: para. 1, Labov 1972c:201). OCLS and LNE are explicitly linked by Labov, who notes after the introduction of the PEC: 'It was just this principle that motivated me to write 'The Logic of Nonstandard English' as part of the general reaction of linguists against uninformed rejection of black children's language as a medium for learning' (OCLS:172, n. 11). Here again is the PEC quoted in full:

A scientist who becomes aware of a widespread idea or social practice with important consequences that is invalidated by his own data is obligated to bring this error to the attention of the widest possible audience. (OCLS:172)

Labov's presentation of the PEC overlaps both OCLS and LNE, and both texts raise mistaken beliefs about language practices racialized as Black before highlighting efforts to correct those beliefs.

Labov's description of the Ann Arbor case consistently emphasizes the knowledge and beliefs of the school staff, who he says 'didn't have the knowledge to evaluate what their tests showed' (OCLS:168). After summarizing research on the origins and linguistic characteristics of AAVE, Labov discusses how linguists responded to the views of some educational psychologists,

that the verbal deprivation of black children was so great that they were best treated as if they had no language at all. ... Creolists, dialectologists, and analysts of variation all agreed that something had to be done about educators who insisted that the only logical answer to the question, 'Where is the squirrel?' is 'The squirrel is in the tree,' and that children who answered 'On the tree' did not show the capacity for logical thought. (OCLS:85)

As he shows at length in LNE, which also discusses the utterance 'in the tree', the educational psychologists who advanced that thesis employ theories of language that consistently deficitize the language of Black children, but he primarily objects that these theories are incorrect in the face of what he sees as objective findings. This treatment implies a theory of language ideology as primarily about information and belief, but this theory is not explored or justified. Labov's objectivist and evidentiary engagement with the work of Bereiter and Engelmann discards an opportunity to understand studies in 'verbal deprivation' as ideologically linked to historically locatable representations of language as something describable in the first place as logical or illogical, deprived or enriched, academic or unsuited for complex thinking. A focus on simply disproving the verbal deprivation thesis thus works against efforts to imagine ways of dismantling the specific sociopolitical conditions it supports.

This focus on knowledge exemplifies the idealist theory of racism that limits the PEC to an evidentiary engagement with verbal deprivation thesis, particularly as it influences educational practice: 
[the verbal deprivation thesis] gives teachers a ready-made, theoretical basis for the prejudice they may [The word may is not included in Language in the inner city] already feel against the lowerclass black child and his language. When they hear him say I don't want none or They mine, they will be hearing, through the bias provided by the verbal-deprivation theory, not an English dialect different from theirs, but the 'primitive mentality of the savage mind.' (LNE; Labov 1972a: para. 137, Labov 1972c:230-31)

In this analysis of the problem of teachers' evaluation of language, Labov proposes that a theory based on unsound science can amplify a teacher's existing prejudice and produce an unsound teaching practice. To prevent the unsound teaching practice, he supplies a new account of students' language that is meant to disprove the deficitizing verbal deprivation theory. This approach focuses on individual teacher prejudice as an essential part of the explanation for the marginalization of Black students. While we cannot ascertain the editorial choices leading to the inclusion of the word may in the version in The Atlantic Monthly, the focus on individual prejudice distracts from considering material and institutional aspects of educational inequity, regardless of how many teachers are imagined to feel prejudice toward Black children.

In the closing paragraph of LNE, Labov refers to the consequences of the verbal deprivation thesis:

That educational psychology should be strongly influenced by a theory so false to the facts of language is unfortunate; but that children should be the victims of this ignorance is intolerable. If linguists can contribute some of their valuable knowledge and energy toward exposing the fallacies of the verbal-deprivation theory, we will have done a great deal to justify the support that society has given to basic research in our field. (LNE; Labov 1972a: para. 187, Labov 1972c:240 with elaboration $)^{2}$

Although advocating linguistic research in this way has likely influenced generations of scholars to engage in activism they otherwise may not have pursued, Labov's analysis of the role of the verbal-deprivation thesis in educational inequity is still limited in important ways. Error correction efforts to resist marginalizing representations of language overlook the root cause of this marginalization by blaming it on a scientific fallacy and not connecting it to the material and historical aspects of racism.

Even where Labov includes reservations about the PEC, he relies on idealist theories of racism to understand the social problem he wants to address. Just after describing how the judge in the case decided that the chief problem 'was in the form of unconscious negative attitudes formed by teachers towards children who spoke Black English, and the reactions of children to those attitudes' (OCLS:193), Labov expresses doubt about an agenda centered on attitudes:

My own view, and the one that I expressed in testimony, is that operations on attitudes alone will not be enough to make a substantial difference to the reading of black children. What is needed is a set of additions to the day-to-day reading curriculum, in order to show the teachers how to deal with students in the classroom who have a different linguistic system than that assumed in the curriculum. (OCLS:194).

This reading curriculum could be called a 'social practice with important consequences' in the language of the PEC. But even though he tempers the emphasis 
on attitudes somewhat, Labov criticizes the reading curriculum in terms of the incorrect information or inadequate knowledge it relies on. Similarly, when Labov (OCLS:168-69) discusses an auditory discrimination skill assessment that 'included a number of oppositions that are mergers in the Black English Vernacular: pin vs. pen, sheaf vs. sheath, clothe vs. clove, and so forth', he describes efforts to present findings on BEV to the creators of the test, which at the time had not yet been successful in changing its administration. Even if it took years, empirical confrontation may have seemed the best possible way to affect these testing practices. But insofar as the theory of change employed by Labov explains the persistence of this 'error' as mainly rooted in a lack of information, it ignores the sociopolitical context that allowed these 'errors' to flourish. After all, a biased test that consistently positioned large numbers of White students as academic failures or as having abnormal hearing would likely be swiftly revised. Thus, even in the case of a seemingly narrow technical matter that did not involve large sections of the public, there are still serious limitations to addressing beliefs and knowledge alone. A language ideological perspective on these representations would seek to understand the interested social positions and material circumstances that are constructed by representations of language embedded in curricula and assessments. A critical race perspective suggests that such biases or oversights must be understood in the context of social processes that contribute to the accumulation of social and material resources among and to White people.

It is toward the closing of OCLS that Labov comes the closest to questioning the PEC. The final sentences of this selection illustrate a measure of skepticism: There remains only the answer to the question posed at the outset: how can we reconcile the objec-
tivity we need for scientific research with the social commitment we need to apply our knowledge in
the social world?

\begin{abstract}
When I first started discussing this case, I thought that the answer was clear. I saw that our most valuable asset was the consensus that had been reached. Once linguists arrive at a common point of view, they can testify effectively in court and in the public forum. The strategy then seemed straightforward: follow the principles of objectivity rigorously and if you are right you will get the evidence you need to convince your colleagues. You can then proceed to follow the principles of commitment with a good chance of success and the knowledge that you haven't biased your scientific work.
\end{abstract}

On closer examination of the record of this research, I've come to recognize that objectivity and commitment can't be partitioned as neatly as that. Commitment is needed at all stages of this research: in entering the field; in dealing with a racist society on both sides of the issue; ${ }^{3}$ withstanding the kinds of criticism that I have cited above. On the other hand, people being what they are, I don't think that any amount of objective evidence will get us to pay proper attention to a theory put forward by someone we don't want to believe is right. (OCLS:194-95)

This selection of OCLS, where Labov expresses his only doubts about the viability of an error correction agenda, also contains the only direct reference to racism, but there is considerable elision in the phrase 'people being what they are' that downplays the intensity of the problem. An appeal to a timeless human nature is not compatible with a language ideological approach that understands representations of language within their political, economic, and social context. CRT perspectives 
would see the appeal to human nature in a discussion of racism as a widely heard and widely employed stock story (Delgado 1989) that normalizes the status quo by describing specific events in history-colonialism, racialization, slavery-as results of an unfortunate quality of people everywhere (Hill 2008:7). Even where Labov comes closest to doubting the idealist premises of the PEC, a stock story of racism is ready-made to explain these doubts away.

Since the publication of OCLS and LNE, when Labov himself has reviewed error correction efforts, he has not offered revision of the PEC or revisited its theory of social change (Gordon 2006; Labov 2016). In an interview conducted by Matthew Gordon, Labov revisits his formulation of the principle of debt incurred and the ways he still strives to repay the debt to the Black community that he incurred by collecting data that led to specific professional benefits for him:

[A] lot of important theoretical conclusions came from the study of African American English. But we didn't improve the reading of the guys we were working with in Harlem in the 1960s. This is a problem that I've returned to. I wrote a paper on objectivity and commitment in linguistic science (1982) and talked about the debt incurred of the scholar who gets information from the community. We're still trying to repay that debt. So over half of my effort over the last ten years has been devoted to trying to raise the reading levels of African Americans and other minority groups in the inner city. If I do make a contribution to that, it will certainly weigh very heavily on the scales. (Gordon 2006:342)

As part of his response to a question about whether Labov has seen 'a change in attitudes toward AAE among classroom teachers' (Gordon 2006:343), he echoes Rickford's (1999) description of the need for repeated messaging:

You may succeed in changing the point of view of a given group of people, but in the meantime, ten or twenty thousand others will arrive in the school system with the same attitude towards everyday vernacular language. (Gordon 2006:343)

Further discussing opposition to certain pedagogical approaches and focusing again on improving the teaching of reading, he says:

\footnotetext{
There are broad general principles controlling people's reaction to everyday language, and the struggle to change them should not be confused with the struggle to improve the reading and writing of the children you're dealing with. Those are two separate enterprises. I don't want to engage in a quixotic effort to change the attitudes of teachers and parents about something that they believe as fundamentally as anything else in their lives. Rather, we're going to use our knowledge of African American English to improve the teaching of reading. (Gordon 2006:343).
}

Here, Labov recognizes problems with attempting to change attitudes on a broad scale, and he separates a project of changing attitudes from a project of improving educational outcomes. Labov is obviously determined to critically evaluate his own contributions to the lives of Black students and it is perhaps unsurprising that his own consideration of the PEC is the most critical among sociolinguists doing similar work. I suggest that Labov is correct here that attitudes and material circumstances are distinct to a degree that necessitates their complete separation in social change efforts. However, to capture the insights of CRT and language ideology scholarship developed since the publication of OCLS and LNE, sociolinguistics must make a more definitive break with the theory of social change involved in the PEC. 
POS S B ILITIES FOR A LTERNATIVES TO THE PRINCIPLE OF ERROR CORRECTION

In formulating the PEC, Labov drew on a widespread theory of racism that downplays its material and institutional basis, and this theory is largely unexamined in subsequent work directed toward error correction. The PEC presents a simple portrait of social problems, highlighting individual mistaken beliefs. In contrast, ideological and critical race perspectives on language insist that dominant representations of language shape common sense responses to creating social change. In the face of endemic social problems like racism, the limitations of the PEC demand alternative approaches to social change that examine historical and political contexts and material consequences of representations of language. In the remainder of this article, I highlight scholarship that examines language, marginalization, and social change in ways outside the limits of error correction. With distinct expression, this scholarship displays stances of critical reflexivity (Foley 2002; Gergen 2009) as a common thread. Critical reflexivity is essential to feminist and other methodologies that argue against the standard of objectivity (e.g. Visweswaran 1994; Craven \& Davis 2013; Tuck \& Yang 2014) and informs critical movements in sociolinguistics and linguistic anthropology that demand attention to disciplinary assumptions as part of any study of language (e.g. Bucholtz 2001; Pennycook 2006; Flores, Spotti, \& García 2016).

My critique of the PEC models critical reflexivity and suggests that sociolinguists contributing to social change must use critical reflexive stances to 'attempt to place one's premises into question, to suspend the 'obvious', to listen to alternative framings of reality and to grapple with the comparative outcomes of multiple standpoints' (Gergen 2009:12). Critiques of objectivity, with the accompanying critical reflexivity that researchers must then keep, have been present within sociolinguistics, but the field's pursuit of social change would benefit from wider recognition of their implications for the error correction approach. For example, Morgan (2001:88) reviews research programs into AAVE and the ways that sociolinguists have conceptualized the African American speech community, concluding by arguing, 'When linguistic facts or descriptions are gathered without acknowledging the ideological precepts inherent in both the disciplinary activity and the attempt to assign significance through plans and polices, linguistics as a science perpetuates the prevailing dominant ideology that language study is objective and neutral'. Rejecting the balm of objectivity offered by Labov in OCLS, Morgan's argument suggests that social-change advocates develop strategies that recognize scholarly output in support of marginalized groups as only one of many representations of language. Wolfram (2015) similarly highlights the ideological nature of research to further develop his earlier assertion (Wolfram 2007) that the sociolinguistic research 'canon' describing African American Language has overlooked or distorted some essential features. As more sociolinguists begin to take for granted that all representations of language, whether generated through scholarship or widely 
reproduced by the public, are always tied to historical conditions and interested social positions, their approaches to social change should move beyond error correction and knowledge dissemination. Critical reflexivity can work to strategically examine how pursuit of objectivity, or any other disciplinary assumption, constrains contributions to social change.

Using a materialist perspective on racism to examine and challenge disciplinary assumptions, Richardson (2015) argues that Labov's writings on African American Vernacular English equivocate on its relationship to both residential segregation and educational outcomes in such a way that 'AAVE is reduced to its entanglement with oppression and pathology' (Richardson 2015:188). While Richardson's argument focuses on how Labov has treated questions of AAVE's convergence and divergence (Labov 2010), she also shows how material aspects of racism have been inadequately treated by sociolinguistic scholarship, revealing what she calls 'the limits of sociolinguistics in its quest to uphold equality, diversity, and social justice' (2015:187). For example, Richardson cites passages in which Labov identifies poverty as the cause of underfunded schools (and thus of 'inadequate instruction' and 'reading failure') and unemployment as the cause of poverty. Richardson (2015:189-90) notes that Labov 'acknowledges and decries racist structural problems oppressing vulnerable Black people', but also that 'these receive scant attention', leaving unexamined 'the major policies, practices, and entities responsible for the oppression of African Americans'. She advances a materialist understanding of racism and poverty that centers 'the active involvement of a web of laws, regulations, and informal rules reinforced by social stigma' (191). For example, we could identify racist schoolfunding laws, not poverty, as the cause of underfunded schools. Richardson's critique illustrates how a materialist understanding of racism can inform the study of representation and evaluation of racialized language practices, and she points to the need for more integrated understandings of language and racial hierarchy.

In fact, not all projects of public engagement in sociolinguistics have depended on error correction approaches and idealist theories of racism, though alternatives have been relatively overlooked. For example, research demonstrating the feasibility and prevalence of linguistic profiling over the telephone as a component of housing discrimination (Purnell, Idsardi, \& Baugh 1999) did not lead to an educational outreach campaign to landlords. Instead, Baugh built a supportive relationship with fair housing agencies and advocacy groups that resulted in a public campaign encouraging those seeking housing to report suspected linguistic profiling as violations of law (Baugh 2003). Smitherman's (1981, 1998, 2004) analysis of institutionalized racism in education includes proposals for a moratorium on all testing and for comprehensive multilingual education policy, not only error correction and knowledge dissemination efforts. Richardson's critique of how racism is understood in Labov's work highlights the stark differences between dominant error correction approaches and the work of Baugh and Smitherman, which have been less celebrated as classic examples of sociolinguistic research in the pursuit of social change. 
Hill (1998:680) provides a model research approach in her agenda for the linguistic anthropology of racism, arguing that racism is not merely 'irrationality' but a phenomenon persisting 'in relatively enduring political ecologies, and lending coherence and meaning to complex and ambiguous human experiences'. She proposes questions about how language practices can normalize racial hierarchy - such as 'What discourse processes socialize children as racial subjects?' and 'What discourse processes relate the racialization of bodies to the racialization of kinds of speech?'- that encourage researchers to investigate, not assume, connections between racism, social change, and representations of language (Hill 1998:681). Whether inspired or not by Hill's specific proposals, research describing the relationship between endemic racism and representations of language not only contributes insights about particular settings but also addresses the serious gap in theorizing social change left by the PEC's dominance within sociolinguistics.

Within the broad agenda Hill explains, to explicitly avoid the problems of the PEC, there is particular need to investigate how academic scholarship has produced and continues to produce knowledge about language in ways linked to existing systems of marginalization. Flores \& Rosa (2015) propose a framework of raciolinguistic ideologies to describe racialized and racializing models of language such as 'Standard English'. Reviewing three categories of students based on supposedly objective models of language-long-term English learners, heritage language learners, and Standard English learners - they show how appropriateness-based approaches to language education 'are implicated in the reproduction of racial normativity by expecting language-minoritized students to model their linguistic practices' along white norms while simultaneously 'perceiving these students' language use in racialized ways' (151). Aggarwal (2016) examines representations of legally enforced segregation and its impact on the education of Black students in the US, as refracted through the Brown v. Board of Education decision and the federally commissioned Coleman and Moynihan reports. Aggarwal explores the ideological and historical precursors of the increasingly influential representations of a 'word gap', which have been used to characterize differences in language used and heard by children of poor and middle class families. She uses Cheryl Harris's (1993) framework of whiteness as property, denoting the historical connections between racial domination and the establishment of norms of property and rights, to explain how the 'word gap' discourse is merely one result of a process in which 'the problem of a continued tiered citizenship in education despite the universal rights to access has come to be represented and resolved as a problem of psyche, capacities, and culture' (Aggarwal 2016:132). This representation thus forms a basis for 'decades of policy reforms and initiatives' that focus on 'the integration of students - rather than desegregation of resources - as the remedy to educational inequity' (Aggarwal 2016:139). Along with other scholars using language ideological and critical race frameworks, Aggarwal and Flores \& Rosa confront ways that marginalizing representations of language are reproduced in linguistic and educational scholarship, showing how critical reflexivity may avoid 
such reproduction, not only around issues of racialization and racism but other forms of marginalization as well.

Critical reflexivity can be applied not only to the documentation of language practices but also to framings of social problems themselves. For example, proposing an agenda for a diverse body of educational research, Ladson-Billings (2006) critiques the contemporary framing of the 'achievement gap' as a research problem and argues instead for asking questions about educational inequality by centering the 'education debt' resulting from the historically accumulated effects of legally enforced white supremacy. Lu \& Horner (2013) also model critically reflexive examination of research questions in their discussion of translingual writing pedagogy, which resists ideologies of monolingualism while promoting the interests of marginalized students in the writing classroom:

\footnotetext{
Against those who would treat such differences as language deficits- 'errors' to be eradicatedcompositionists have defended the logic, legitimacy, and right of students to write differently. The continuing denigration of subordinated groups through attacks on their language requires that such work continue. At the same time, however, we also need to challenge the assumptions about language responsible in the first place for rendering those differences recognizable as deviations meriting denigration. That is, when responding to attacks on specific language practices, we need to contest, rather than work within, the assumptions underlying the ideological frameworks of the arguments to which we are responding. (Lu \& Horner 2013:583)
}

While Lu \& Horner here might appear to promote a 'both-and' approach, adopting their project of challenging assumptions about language would, at least in some circumstances, preclude efforts to support marginalized language practices by designating them as 'logical' or 'legitimate', descriptions that have long been employed in the interests of elites (e.g. Bauman \& Briggs 2000). Still, Lu \& Horner model critical reflexivity here by explicitly engaging with their own framing of a social problem to consider its affordances, limitations, and tensions.

Examining the Ann Arbor case while attending to the tension that Lu \& Horner highlight, it seems linguists insisting on the logic or rule-governedness of Black language practices could not simultaneously challenge the idea that language practices racialized as Black could be objectified by dominant institutions in a project of evaluating their worth. The struggles of the Black children in Ann Arbor schools came to be defined in terms of evaluations based on ignorance of linguistic fact, rather than political and economic structures allowing these evaluations in the first place. PEC-inspired efforts targeted beliefs for correction, thus limiting potential responses to demonstrations that widespread representations of language were merely false. Responses informed by critical race theory and language ideological approaches would instead center more difficult and fundamental questions of the sociohistorical conditions of a representation of language, challenging its premises and showing its connections to racial, economic, or other forms of violence. Then, although specific social change efforts that begin with these questions in mind will be as diverse as the problems they respond to, sociolinguists should see the validity of marginalized language practices not as a scientific fact, but a political demand. 
My argument shows how a critical reflexive examination of the PEC's starting theoretical assumptions reveals its counterproductive reliance on an individual-centered theory of language ideology and often, in its original articulations in OCLS and LNE as well as subsequent applications, on idealist theories of racism. Critical reflexivity serves to check assumptions of what a social problem entails and what social change requires, but it cannot by itself supply the diverse political strategies beyond error correction that remain to be refined or more widely adopted. By critiquing the theoretical assumptions of the PEC, which does not address research design and explicitly assumes that data collection is effectively completed, my argument has not explored potential for critical reflexivity in design of research or in relationships with partnerships. The critical reflexive examinations of how sociolinguists understand social problems offered by this article could be productively combined with methodologies of prolonged and collaborative research relationships, such as ethnographic monitoring (Hymes 1980; Hornberger 2014), accompaniment (Bucholtz, Casillas, \& Lee 2016), or culturally responsive methodologies (Berryman, SooHoo, \& Nevin 2013), but this potential cannot be adequately explored here.

While no single comprehensive 'principle of critical reflexivity' could be written to capture the iterative work it requires, the work presented in this section suggests some questions that may help sociolinguists avoid the limitations of the PEC, if they are in possession of data and want to act on a commitment to social change:

(i) How do these data reflect a social problem?

(ii) How else can this problem be explained?

(iii) What are the affordances and limitations of my choices in framing the social change goals of my project?

Question (i) identifies areas of potential intersection of research and social change and demands transparency about how these are understood. Question (ii) suggests that it is no simple matter to trace symptoms back to a problem, and it is also a caution against isolating a single factor, such as individual beliefs. Question (iii) requires the researcher to examine their own framing of a social problem and consider alternatives. Part of the PEC's legacy is a warning that a social problem can be widely understood in ways that obfuscate it. Questions like these could guard against limited and potentially counterproductive understandings of social problems.

Guided by the caution that 'it is always easier to detect positioning in the views of others, such as the linguists and ethnographers of an earlier era, than in one's own' (Irvine \& Gal 2000:36), I have tried to present my critique in the spirit of serving the same drive to somehow change society for the better that has moved Labov and sociolinguists who attempt error correction. I hope that my critique of the work 'of an earlier era' not only contributes to a search for specific alternatives to the PEC, mindful of its serious limitations, but also deepens the spirit of critical and collaborative reflexivity within sociolinguistics. This work will be difficult and constant, but it can only aid the commitments to social change that so many sociolinguists share. 


\section{A CRITIQUE OF THE PRINCIPLE OF ERROR CORRECTION}

\section{N O T E S}

*I wish to thank Nelson Flores, Robert Moore, Jennifer Phuong, and Aldo Anzures Tapia, as well as Jenny Cheshire and two anonymous reviewers, for their helpful feedback on earlier versions of this article. I also appreciated the feedback of attendees of a videoconference sponsored by the PennKing's Link, with faculty and students from King's College London (Language, Discourse \& Communication) and the University of Pennsylvania (Educational Linguistics). Finally, thank you to Diane Downer Anderson, who provided space for the very earliest version of this article to form.

${ }^{1}$ When referencing another work, I employ its terminology. When I refer to these practices generally or across scholarly works, I use the term language practices racialized as Black in recognition that these language practices are subject to language ideological processes and racialization.

${ }^{2}$ Before the final sentence of the paragraph, the 1972 print version includes: 'It may seem that the fallacies of the verbal deprivation theory are so obvious that they are hardly worth exposing. I have tried to show that such exposure is an important job for us to undertake'. Likely omitted in the interest of abridgement, this material strengthens the impression that Labov mainly frames the theory as false.

${ }^{3}$ These two 'sides' may refer to the fact that the history of racism made some in the Black community suspicious of White scholars separating 'Black English' from 'English'. One example of this suspicion mentioned in OCLS is an issue of the NAACP newsletter The Crisis voicing intense skepticism about the invention of 'Black English' by White liberals (OCLS:177-78). For more on Black responses to sociolinguistic research see Morgan (2001) and Smitherman (1998).

\section{R E F E R E N C ES}

Aggarwal, Ujju (2016). The ideological architecture of whiteness as property in educational policy. Educational Policy 30(1):128-52.

Alim, H. Samy (2010). Critical language awareness. In Nancy H. Hornberger \& Sandra Lee McKay (eds.), Sociolinguistics and language education, 205-31. Bristol: Multilingual Matters.

(2016). Introducing raciolinguistics: Racing language and languaging race in hyperracial times. In H. Samy Alim, John R. Rickford, \& Arnetha F. Ball (eds.), Raciolinguistics: How language shapes our ideas about race, 1-30. Oxford: Oxford University Press.

— \& Geneva Smitherman (2012). Articulate while Black: Barack Obama, language, and race in the U.S. Oxford: Oxford University Press.

Avineri, Netta; Eric Johnson; Shirley Brice-Heath; Teresa McCarty; Elinor Ochs; Tamar Kremer-Sadlik; Susan Blum; Ana Celia Zentella; Jonathan Rosa; Nelson Flores; H. Samy Alim; \& Django Paris (2015). Invited Forum: Bridging the 'language gap'. Journal of Linguistic Anthropology 25(1):66-86.

Bauer, Laurie, \& Peter Trudgill (eds.) (1998). Language myths. London: Penguin Books.

Baugh, John (2000). Beyond Ebonics: Linguistic pride and racial prejudice. Oxford: Oxford University Press.

- (2003). Linguistic profiling. In Sinfree Makoni, Geneva Smitherman, Arnetha F. Ball, \& Arthur K. Spears (eds.), Black linguistics: Language, society, and politics in Africa and the Americas, 15568. New York: Routledge.

Bauman, Richard, \& Charles L. Briggs (2000). Language philosophy as language ideology: John Locke and Johann Gottfried Herder. In Paul V. Kroskrity (ed.), Regimes of language: Ideologies, polities, and identities, 139-204. Santa Fe, NM: School of American Research Press.

Bell, Derrick A. (1980). Brown vs. Board of Education and the interest-convergence dilemma. Harvard Law Review 93(3):518-33.

Berryman, Mere; Suzanne SooHoo; \& Ann Nevin (2013). Culturally responsive methodologies from the margins. In Mere Berryman, Suzanne SooHoo, \& Ann Nevin (eds.), Culturally responsive methodologies, 1-31. Bingley: Emerald.

Bonfiglio, Thomas Paul (2002). Race and the rise of standard American. New York: Mouton de Gruyter. Bucholtz, Mary (1999). You da man: Narrating the racial other in the production of white masculinity. Journal of Sociolinguistics 3(4):443-60.

Language in Society 47:3 (2018) 
(2001). Reflexivity and critique in discourse analysis. Critique of anthropology 21(2):165-83. ; Dolores Inés Casillas; \& Jin Sook Lee (2016). Beyond empowerment: Accompaniment and sociolinguistic justice in a youth research program. In Robert Lawson \& Dave Sayers (eds.), Sociolinguistic research: Application and impact, 25-44. New York: Routledge.

Craven, Christa, \& Dana-Ain Davis (2013). Introduction: Feminist activist ethnography. In Christa Craven \& Dana-Ain Davis (eds.), Feminist activist ethnography: Counterpoints to neoliberalism in North America, 1-20. Lanham, MD: Lexington Books.

Crump, Alison (2014). Introducing LangCrit: Critical language and race theory. Critical Inquiry in Language Studies 11(3):207-24.

Delgado, Richard (1989). Storytelling for opportunists and others: A plea for narrative. Michigan Law Review 87:2411-41.

, \& Jean Stefancic (2001). Critical race theory: An introduction. New York: New York University Press.

Flores, Nelson (2016). A tale of two visions: Hegemonic whiteness and bilingual education. Educational Policy 30(1):13-38.

- \& Jonathan Rosa (2015). Undoing appropriateness: Raciolinguistic ideologies and language diversity in education. Harvard Educational Review 85(2):149-71.

— Ofelia García, Nelson Flores, \& Massimiliano Spotti (eds.), The Oxford handbook of language and society, 545-51. Oxford: Oxford University Press.

Foley, Douglas E. (2002). Critical ethnography: The reflexive turn. International Journal of Qualitative Studies in Education 15(4):469-90.

Gergen, Kenneth J. (2009). An invitation to social construction. 2nd edn. Los Angeles, CA: SAGE.

Gillborn, David (2005). Education policy as an act of white supremacy: Whiteness, critical race theory and education reform. Journal of Education Policy 20(4):485-505.

Gordon, Matthew J. (2006). Interview with William Labov. Journal of English Linguistics 34(4):332-51.

Harris, Angela (2001). Foreword. Critical race theory: An introduction, xvii-xxi. New York: New York University Press.

Harris, Cheryl I. (1993). Whiteness as property. Harvard Law Review 106(8):1707-91.

Hill, Jane H. (1998). Language, race, and white public space. American Anthropologist 100(3):680-89.

(2008). The everyday language of white racism. Malden, MA: Wiley-Blackwell.

Hornberger, Nancy H. (2014). On not taking language inequality for granted: Hymesian traces in ethnographic monitoring of South Africa's multilingual language policy. Multilingua 33(5-6):623-45.

Hymes, Dell (1980). Ethnographic monitoring. Language in education: Ethnolinguistic essays, 104-18. Washington, DC: Center for Applied Linguistics.

Irvine, Judith T., \& Susan Gal (2000). Language ideology and linguistic differentiation. In Paul V. Kroskrity (ed.), Regimes of language: Ideologies, polities, and identities, 35-83. Santa Fe, NM: School of American Research Press.

Johnson, David Cassels (2013). Language policy. New York: Palgrave Macmillan.

Kroskrity, Paul V. (2000). Regimenting languages: Language ideological perspectives. In Paul V. Kroskrity (ed.), Regimes of language: Ideologies, polities, and identities, 1-35. Santa Fe, NM: School of American Research Press.

Kubota, Ryuko, \& Angel Lin (2006). Race and TESOL: Introduction to concepts and theories. TESOL Quarterly 40(3):471-93.

Labov, William (1972a). Academic ignorance and Black intelligence. The Atlantic Monthly June. Online: http://www.theatlantic.com/past/docs/issues/95sep/ets/labo.htm.

(1972b). Language in the inner city: Studies in the Black English Vernacular. Philadelphia, PA: University of Pennsylvania Press.

(1972c). The logic of nonstandard English. In Language in the inner city: Studies in the Black English Vernacular, 201-240. Philadelphia, PA: University of Pennsylvania Press. 


\section{A CRITIQUE OF THE PRINCIPLE OF ERROR CORRECTION}

(1982). Objectivity and commitment in linguistic science: The case of the Black English trial in Ann Arbor. Language in Society 11(2):165-201.

- (2010). Unendangered dialect, endangered people: The case of African American Vernacular English. Transforming Anthropology 18(1):15-27.

(2016). Afterword: Where are we now? Journal of Sociolinguistics 20(4):581-602.

Ladson-Billings, Gloria (2006). From the achievement gap to the education debt: Understanding achievement in US schools. Educational researcher 35(7):3-12.

\& William F. Tate (1995). Toward a critical race theory of education. Teachers College Record 97(1):47-68.

Lawson, Robert, \& Dave Sayers (2016). Where we're going, we don't need roads. In Robert Lawson \& Dave Sayers (eds.), Sociolinguistic research: Application and impact, 7-22. London: Routledge.

Lippi-Green, Rosina (1997). English with an accent: Language, ideology, and discrimination in the United States. New York: Routledge.

Lu, Min-Zhan, \& Bruce Horner (2013). Translingual literacy, language difference, and matters of agency. College English 75(6):582.

McWhorter, John H. (1998). Word on the street: Debunking the myth of 'pure' Standard English. Cambridge, MA: Pereus.

Milroy, James, \& Lesley Milroy (1999). Authority in language: Investigating standard English. New York: Routledge.

Milroy, Lesley, \& Matthew Gordon (2003). Sociolinguistics: Method and interpretation. 2nd edn. Malden, MA: Wiley-Blackwell.

Morgan, Marcyliena (1994). Theories and politics in African American English. Annual Review of Anthropology 23:325-45.

_ (2001). The African-American speech community: Reality and sociolinguists. In Alessandro Duranti (ed.), Linguistic anthropology: A reader, 74-94. Malden, MA: Blackwell.

Mufwene, Salikoko S. (2001). What is African American English? In Sonja L. Lanehart (ed.), Sociocultural and historical contexts of African American English, 21-51. Amsterdam: John Benjamins.

Pennycook, Alastair (2006). Critical applied linguistics. In Keith Brown (ed.), Encyclopedia of language \& linguistics, 2nd edn., 283-90. Oxford: Elsevier.

Purnell, Thomas; William Idsardi; \& John Baugh (1999). Perceptual and phonetic experiments on American English dialect identification. Journal of Language and Social Psychology 18(1):10-30.

Rice, Keren (2007). Ethical issues in linguistic fieldwork: An overview. Journal of Academic Ethics 4(1-4):123-55.

Richardson, Elaine (2015). When language is and not the issue: The case of 'AAVE' literacy research, teaching, and Labov's prescription for social (in)equality. In Martha Bigelow \& Johanna EnnserKananen (eds.), The Routledge handbook of educational linguistics, 185-94. New York: Routledge.

Rickford, John R. (1997). Unequal partnership: Sociolinguistics and the African American speech community. Language in Society 26(2):161-97.

(1999). The Ebonics controversy in my backyard: A sociolinguist's experiences and reflections. Journal of Sociolinguistics 3(2):267-75.

(2016). Labov's contributions to the study of African American Vernacular English: Pursuing linguistic and social equity. Journal of Sociolinguistics 20(4):561-80.

Rosa, Jonathan (2016). Racializing language, regimenting Latinas/os: Chronotope, social tense, and American raciolinguistic futures. Language \& Communication 46:106-17.

— , \& Christa Burdick (2016). Language ideologies. In Ofelia García, Nelson Flores, \& Massimiliano Spotti (eds.), The Oxford handbook of language in society, 103-23. Oxford: Oxford University Press.

Silverstein, Michael (1985). Language and the culture of gender: At the intersection of structure, usage, and ideology. In Elizabeth Mertz \& Richard J. Parmentier (eds.), Semiotic mediation: Sociocultural and psychological perspectives, 219-59. Orlando: Academic Press. 
Smitherman, Geneva (1981). 'What go round come round': King in perspective. Harvard Educational Review 51(1):40-56.

(1998). Ebonics, King, and Oakland: Some folk don't believe fat meat is greasy. Journal of English Linguistics 26(2):97-107.

(2004). Language and African Americans: Movin on up a lil higher. Journal of English Linguistics 32(3):186-96.

(2015). African American Language and education: History and controversy in the twentieth century. In Sonja L. Lanehart (ed.), The Oxford handbook of African American Language, 54765. New York: Oxford University Press.

Smitherman-Donaldson, Geneva (1988). Discriminatory discourse on Afro-American speech. In Geneva Smitherman-Donaldson \& Teun A. van Dijk (eds.), Discourse and discrimination, 14471. Detroit, MI: Wayne State University Press.

Tuck, Eve, \& K. Wayne Yang (2014). R-words: Refusing research. In Django Paris \& Maisha T. Winn (eds.), Humanizing research: Decolonizing qualitative inquiry with youth and communities, 223-48. Thousand Oaks, CA: SAGE.

Visweswaran, Kamala (1994). Fictions of feminist ethnography. Minneapolis: University of Minnesota Press.

Wassink, Alicia Beckford, \& Anne Curzan (2004). Addressing ideologies around African American English. Journal of English Linguistics 32(3):171-85.

Wiley, Terrence G. (1997). Myths about language diversity and literacy in the United States. ERIC Digest. Online: http://eric.ed.gov/?id=ED407881; accessed 12 February 2015.

Wolfram, Walt (1993). Ethical considerations in language awareness. Paper presented at the American Association of Applied Linguistics Ethics Symposium.

(1997). Dialect in society. In Florian Coulmas (ed.), The handbook of sociolinguistics, 107-26. Cambridge, MA: Blackwell.

(1998). Language ideology and dialect. Journal of English Linguistics 26(2):108-21.

(2007). Sociolinguistic folklore in the study of African American English. Language and Linguistics Compass 1(4):292-313.

- (2015). The sociolinguistic construction of African American Language. In Sonja L. Lanehart (ed.), The Oxford handbook of African American Language, 338-52. New York: Oxford University Press.

(2016). Public sociolinguistic education in the United States: A proactive, comprehensive program. In Robert Lawson \& Dave Sayers (eds.), Sociolinguistic research: Application and impact, 87-107. London: Routledge.

Woolard, Kathryn A. (1998). Language ideology as a field of inquiry. In Bambi B. Schieffelin, Kathryn A. Woolard, \& Paul V. Kroskrity (eds.), Language ideologies: Practice and theory, 3-47. Oxford: Oxford University Press.

— \& Bambi B. Schieffelin (1994). Language ideology. Annual Review of Anthropology 23:55-82.

Zuidema, Leah A. (2005). Myth education: Rationale and strategies for teaching against linguistic prejudice. Journal of Adolescent \& Adult Literacy 48(8):666-75.

(Received 07 July 2016; revision received 21 April 2017; accepted 25 May 2017)

Address for correspondence:

Mark C. Lewis

University of Pennsylvania,

Graduate School of Education

3700 Walnut Street,

Philadelphia, PA 19143, USA

markle@gse.upenn.edu 